\title{
Functional analysis of Leifsonia xyli subsp. xyli membrane protein gene Lxx 18460 (anti-sigma K)
}

\author{
Kai Zhu', Min Shao', Dan Zhou', Yong-Xiu Xing ${ }^{1}$, Li-Tao Yang ${ }^{1,2^{*}}$ and Yang-Rui Li ${ }^{1,2^{*}}$ (D)
}

\begin{abstract}
Background: Sugarcane is an important sugar and economic crop in the world. Ratoon stunting Disease (RSD) of sugarcane, caused by Leifsonia xyli subsp. xyli, is widespread in countries and regions where sugarcane is grown and also limited to sugarcane productivity. Although the whole genome sequencing of Leifsonia xyli subsp. xyli was completed, progress in understanding the molecular mechanism of the disease has been slow because it is difficult to grow in culture.
\end{abstract}

Results: The Leifsonia xyli subsp. xyli membrane protein gene Lxx18460 (anti-sigma K) was cloned from the Lxxinfected sugarcane cultivar GT11 at the mature stage using RT-PCR technique, and the gene structure and expression in infected sugarcane were analyzed. The Lxx18460 gene was transformed into Nicotiana tabacum by Agrobacterium tumefaciens-mediation. The transgenic tobacco plants overexpressing $L x \times 18460$ had lower levels in plant height, leaf area, net photosynthetic rate and endogenous hormones of IAA, ABA and $\mathrm{GA}_{3}$, as well as lower activities of three antioxidant enzymes, superoxide dismutase (SOD), peroxidase (POD) and catalase (CAT) than the wild type (WT) tobacco. With the plant growth, the expression of Lxx18460 gene and protein was increased. To better understand the regulation of $L \times 18460$ expression, transcriptome analysis of leaves from transgenic and wild type tobacco was performed. A total of 60,222 all-unigenes were obtained through BGISEQ-500 sequencing. Compared the transgenic plants with the WT plants, 11,696 upregulated and 5949 downregulated genes were identified. These differentially expressed genes involved in many metabolic pathways including signal transduction, biosynthesis of other secondary metabolism, carbohydrate metabolism and so on. Though the data presented here are from a heterologous system, $L x x 18460$ has an adverse impact on the growth of tobacco; it reduces the photosynthesis of tobacco, destroys the activity of defense enzymes, and affects the levels of endogenous hormones, which indicate that $L \times 18460$ may act important roles in the course of infection in sugarcane.

Conclusions: This is the first study on analyzing the function of the membrane protein gene $L \times 18460$ of antisigma K (ఠK) factor in Leifsonia xyli subsp. xyli. Our findings will improve the understanding of the interaction between the RSD pathogen Leifsonia xyli subsp. xyli and sugarcane. The output of this study will also be helpful to explore the pathogenesis of RSD.

Keywords: Ratoon stunting disease, Lxx18460, Transgenic tobacco, Transcriptome, Functional analysis

\footnotetext{
* Correspondence: liyr@gxu.edu.cn; liyr@gxaas.net

${ }^{1}$ College of Agriculture, State Key Laboratory of Conservation and Utilization

of Subtropical Agro-bio resources, Guangxi University, Nanning 530005,

China

Full list of author information is available at the end of the article
}

(c) The Author(s). 2019 Open Access This article is distributed under the terms of the Creative Commons Attribution 4.0 International License (http://creativecommons.org/licenses/by/4.0/), which permits unrestricted use, distribution, and reproduction in any medium, provided you give appropriate credit to the original author(s) and the source, provide a link to the Creative Commons license, and indicate if changes were made. The Creative Commons Public Domain Dedication waiver (http://creativecommons.org/publicdomain/zero/1.0/) applies to the data made available in this article, unless otherwise stated. 


\section{Background}

Sugarcane is an important economic crop in Guangxi province which contributes more than $60 \%$ of the total sugar production in China [1,2]. Ratoon stunting disease (RSD), caused by a nutritionally fastidious Gram-positive bacterium (Leifsonia xyli subsp. xyli $L x x$ ), is widespread in worldwide sugarcane production areas $[3,4]$ and responsible for substantial losses in yield [5-8]. RSD control measures include meristem tissue culture, sterilization of harvesting and planting equipment and seedcane heat treatment. However, all of these measures have limited efficacy, RSD persists in sugarcane as a major threat to sugar industry.

$L x x$ colonizes at xylem vessels, mesophyll and bundle sheath cells surrounding the vascular system $[9,10]$. $L x x$ is genetically uniform, and it has no genetic variation [7, 11]. The whole genome sequencing of $L x x$ (CTCB07) was completed by Monteiro-Vitorello et al. [12]. The sequencing results have caused research interests in host recognition, pathogenicity gene and infection mechanism. Two possible pathogenicity genes, that is, pectinase and cellulose genes would be involved in cell wall degradation, but no evidence of this in the electron micrographs has been shown in the literature $[13,14]$. Other pathogenicity genes may be involved in the production of abscisic acid, which inhibits growth of sugarcane [12]. No any definite disease-causing gene has been found up to now.

$L x x$ is a bacterium, $\sigma$ factor is one of protein subunits $\left(\alpha_{2} \beta \beta^{\prime} \sigma\right)$ of the bacterial RNA polymerase holoenzyme and also a major regulatory factor of prokaryotic gene expression regulation. It can be used to identify the target gene promoter regions, promote the combination of the target region and RNA polymerase holoenzyme [15], and anti $\sigma$ factors could suppress the transcription by affecting the $\sigma$ factor failing to identify the promoter protein conformation or failing to form RNA polymerase holoenzyme. The first anti $\sigma$ factor AsiA was cloned in 2002 [16], and since then many anti $\sigma$ factors have been cloned subsequently $[17,18]$. A transmembrane anti $\sigma$ factor RseA is the product of co-transcription by downstream genes $\sigma^{\mathrm{ECF}}$ and $\sigma^{\mathrm{E}}$ in Escherichia coli, which tightly binds to $\sigma^{\mathrm{E}}$, then restricts its identification of promoter and its binding with the core enzyme of RNA polymerase [19]. Rv0444c of Mycobacterium tuberculosis encodes anti-Sigma $\mathrm{K}$ factor (RskA), which could inhibit the Sigma $K$ regulating action and affect the antigen protein expression of MPB70 and MPB83 ultimately [20]. The $\sigma \mathrm{R}$ factor (sigma $\mathrm{R}$ factor, SigR) activity is regulated by the anti $\sigma$ factor (regulator of sigma R, RsrA) of genus Streptomyces [21]. Previous studies showed that there are huge differences among anti $\sigma$ factors in sequence and structure, and these differences led the anti $\sigma$ factors to react to stimulus response and improve flexibility in bacterial transcriptional regulation [22].

Transcription is the first step of gene expression, and $\sigma$ factor plays a key role in starting transcription, so studies on $\sigma$ factor and anti $\sigma$ factor are considered the key for regulating the gene expression in recent years. However, it is hard to culture $L x x$ in vitro, and the pathogenesis research on RSD is still at a preliminary stage. The anti $\sigma$ factors of $L x x$ and their corresponding features and functionalities have not been sufficiently analyzed. In this study, we isolated and cloned the membrane protein gene $L x x 18640$ (anti-sigma K factor, RskA) of $L x x$, analyzed its biological characteristics, detected its expression in infected sugarcane, and verified its expression in a heterologous system, to further discern its functional role.

\section{Results}

Molecular characterization and bioinformatics analysis of Lxx18460

A full-length $L x x 18460 \mathrm{cDNA}$ was isolated from the infected sugarcane. It was $720 \mathrm{bp}$ in size and the predicted molecular weight of Lxx18460 protein was $24.8 \mathrm{kDa}$ with an isoelectric point (pI) of 5.01 (see Additional file 1). The sequencing results showed that its homology with the $\operatorname{Lxx}$ (NC_006087) from GenBank was up to $100 \%$, and has been registered with the accession No. JQ740153.

There is a conserved domain in the deducted Lxx18460 protein through NCBI CDD (Conserved Domain Databases) (see Additional file 1). The results of functional analysis of $L x x 18460$ using software of SMART and Motif Scan showed that the Lxx18460 protein domain located at the 43-238 position is RskA family (anti o $\mathrm{K}$ factor). The prediction of the transmembrane region of Lxx18460 shows that there is a transmembrane region, which is located between 92 and $114 \mathrm{bp}$. The amino acid sequence homology of Lxx18460 is low as compared to other strains (Fig. 1). BLAST analysis indicated that Lxx18460 had 34\% identity to Arthrobacter arilaitensis, $42 \%$ to marine actinobacterium PHSC20C1, 41\% to Microbacterium testaceum, and $39 \%$ to Clavibacter michiganensis subsp. michiganensis, respectively. The results suggested that the anti o factor has huge differences in structure and sequence in different Leifsonia xylem strains.

\section{Expression of $L x x 18460$ gene in $L x x$-infected sugarcane}

Real-time PCR results showed that the $L x x 18460$ gene was expressed in $L x x$-infected sugarcane stalks and leaves at mature stage, however, for different tissues, the relative expression level was different in different organs (Fig. 2). The highest relative expression was found in internode 1, and there was no obvious difference 


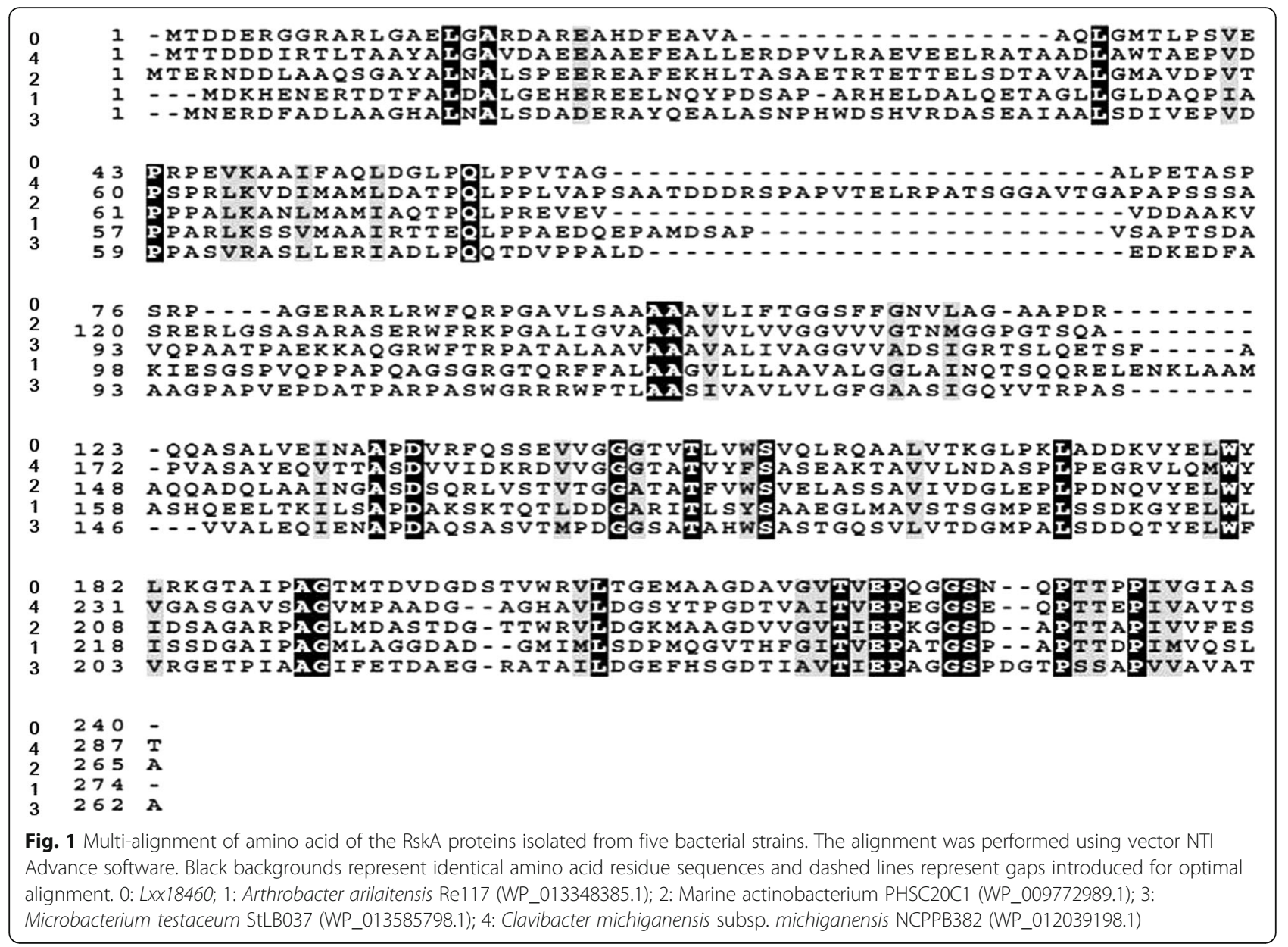

between internode 3 and internode 5 . The relative expression level showed decreasing gradually from internode 1 to stem tip where it was almost zero. The relative expression level was lower in leaves than stems, and it decreased gradually from leaf +5 to leaf +1 .
Transgenic expression of $L x x 18460$ in tobacco

Forty-five independent putative transgenic tobacco calli were produced after co-cultivation of wild-type calli with Agrobacterium tumefaciens carrying Lxx18460 in its T-DNA. The twenty-one putative transgenic plants

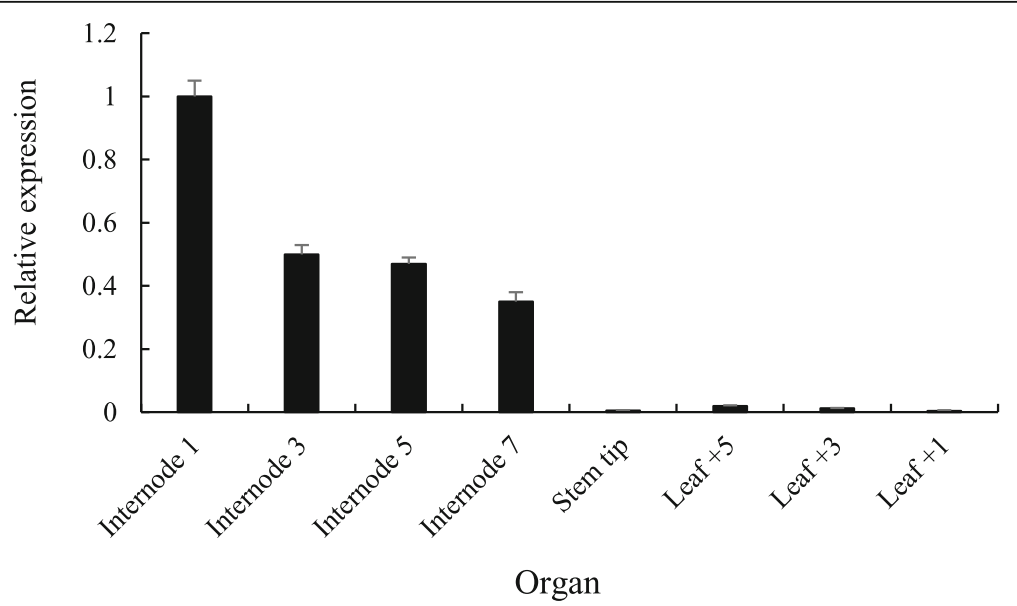

Fig. 2 Expression of $L x \times 18460$ gene in stalks and leaves of sugarcane infected with $L x x$ at maturing stage 
regenerated were screened on a medium containing kanamycin $\left(100 \mathrm{mg} \mathrm{L}^{-1}\right)$, and fifteen of them were found having Lxx18460 gene, NPTII by PCR detection (see Additional file 2). The result of PCR analysis indicated that the co-transformation rate of $L x \times 18460$ and NPTII genes was approximately $71 \%$. The transgenic and WT tobacco plants were further detected with Western Blot using Lxx18460 monoclonal antibody and the results showed that the $L \times x 18460$ gene had been successfully integrated into the transgenic plants and expressed (Fig. 3). Simultaneously, we got the correct sizes of Lxx18460 and NPTII fragment in all the transgenic plants, and found that the Lxx18460 and the NPTII gene existed in all the transgenic plants but not in WT tobacco.

The WT and transgenic plants showed big difference in phenotype (Fig. 4). Compared with WT, the transgenic tobacco showed shorter plant height, finer stem, smaller leaf with slightly fold on the edge. These results suggest that the expression of $L x \times 18460$ might have affected the growth of the transgenic plants.

\section{Expression of $L x x 18460$ gene decreased plant height, leaf} area and net photosynthetic rate in tobacco

The plant height, leaf area and net photosynthetic rate in WT and transgenic tobacco (TT) were compared. As shown in Fig. 5a and b, the plant height and leaf area were lower in TT than in WT from 50 to 110 days after emergence, and there were obvious differences between TT and WT. Net photosynthetic rate was higher in WT than that in TT (Fig. 5c).

Expression of $L x x 18460$ gene declined the SOD, POD, CAT and T-AOC activities in tobacco leaves

The SOD, POD, CAT and T-AOC activities in tobacco leaves were measured at different time. The results showed that the CAT, POD and SOD activities were lower in TT than WT plants (Fig. 6a-c). As compared to $\mathrm{TT}$, the T-AOC activity was significantly higher in WT, suggesting that the total antioxidant capacity is weaken in TT and stronger in WT (Fig. 6d).

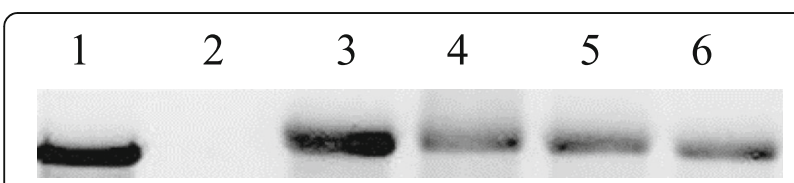

Fig. 3 Western blot of transgenic tobacco lines transformed with Lxx18460 monoclonal antibody. Lines from left to right: lane 1, positive control (purified Lxx18460 protein); lane 2, WT tobacco plant; lanes 3-6, transgenic plants

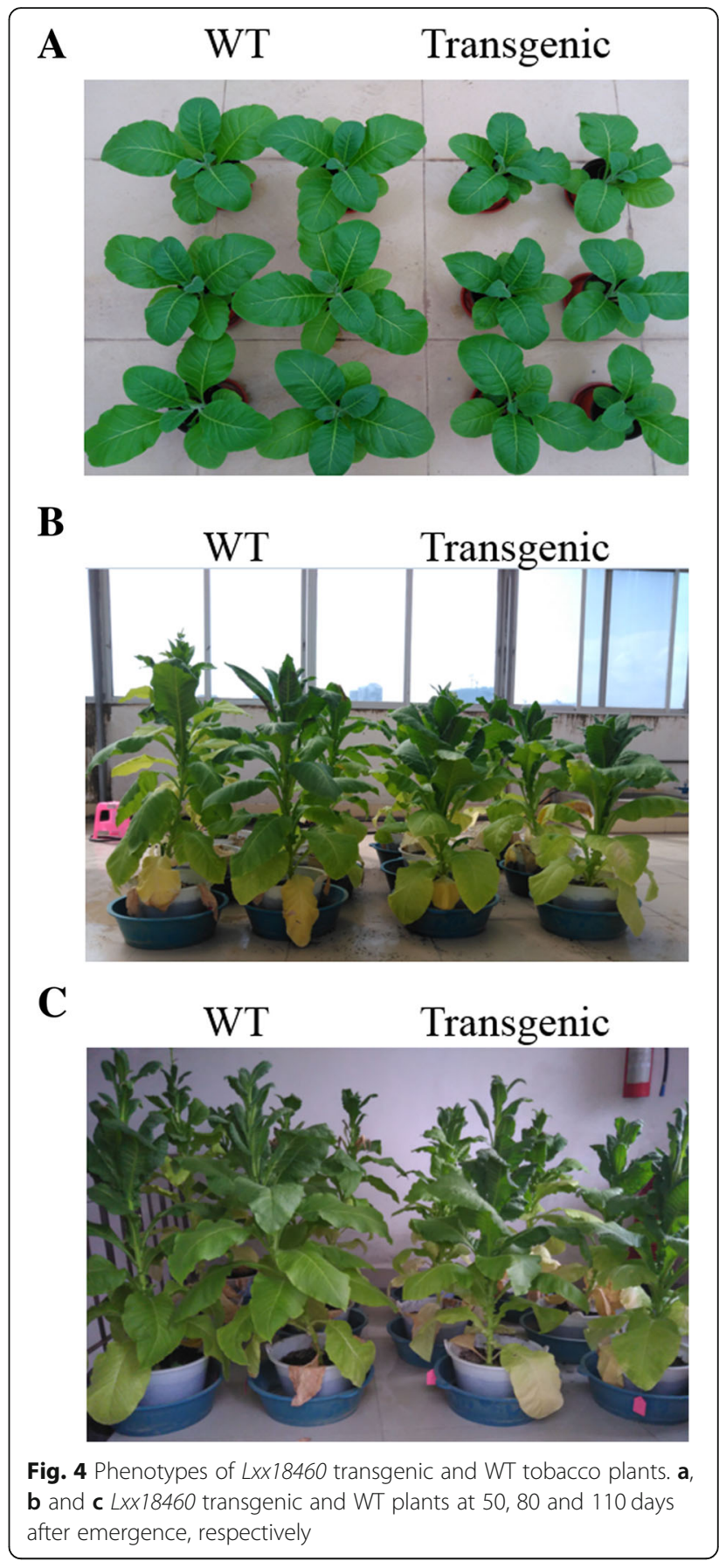

$I A A, A B A$ and $G A_{3}$ contents in tobacco leaves

Compared with the WT, the IAA, ABA and $\mathrm{GA}_{3}$ contents in leaves were significantly lower in the transgenic tobacco plants (Fig. 7).

\section{Lxx18460 gene expression in transgenic tobacco plant}

The $L x x 18460$ gene expression in transgenic tobacco was detected with qRT-PCR, and the results showed that the relative expression of $L x x 18460$ gene was increasing 

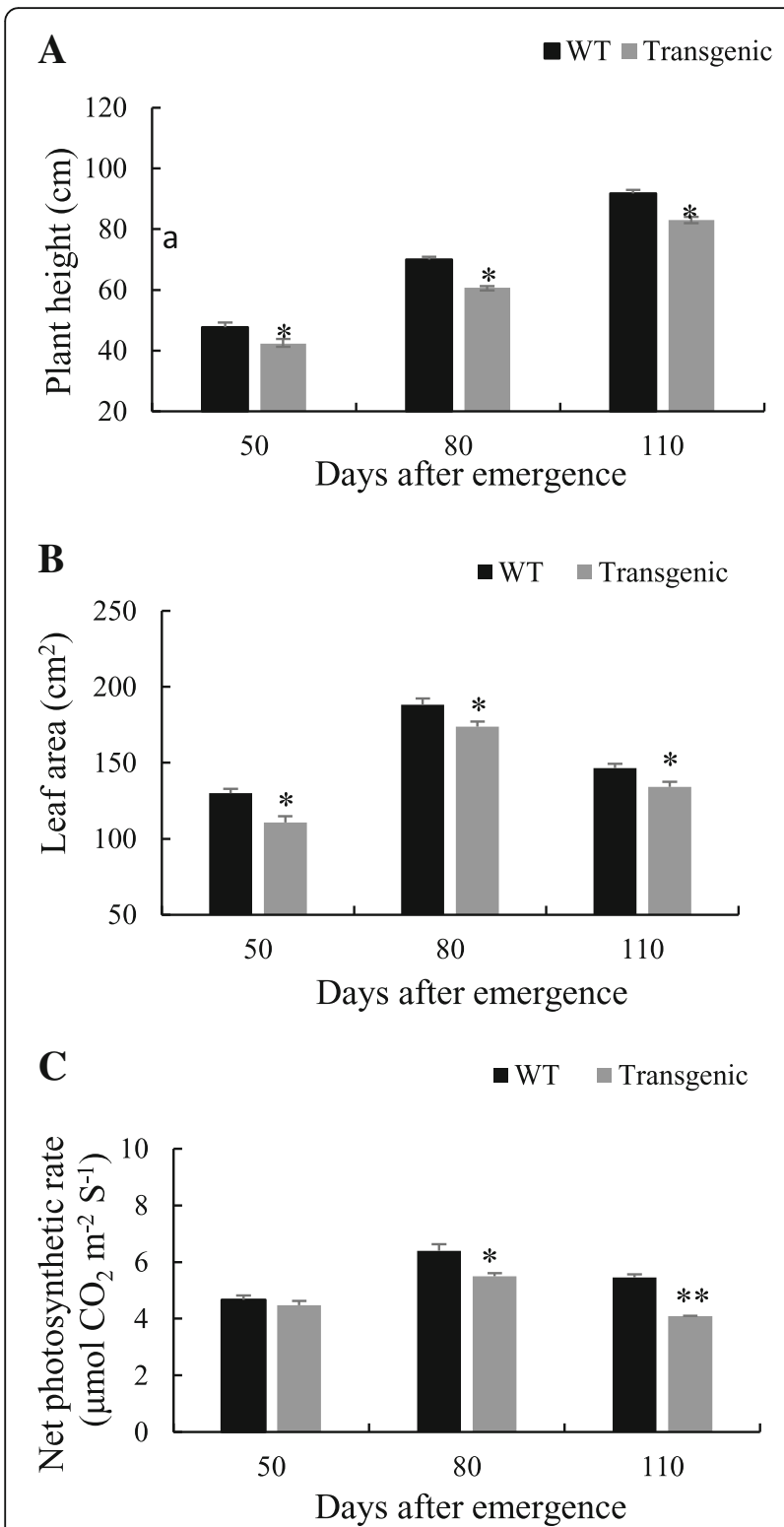

Fig. 5 Plant height (a), leaf area (b), and net photosynthetic rate (c) in transgenic and WT tobacco plants. Tobacco leaf samples were taken at 50, 80 and 110 days after emergence. All the data are means \pm SD calculated from six replicates. Symbols * and ** indicate significant difference between lines at 0.05 and 0.01 levels, respectively. Six biological experiments were performed, which produced similar results

with plant age and significantly higher in stalk and at 110 day after emergence (Fig. 8).

Lxx18460 protein expression in transgenic tobacco plant The Lxx18460 protein expression in the transgenic tobacco was detected with Western Blot, and the results (Fig. 9a) showed that the relative expression of Lxx18460 protein was accorded with the $L x x 18460$ gene expression in the transgenic tobacco plant, which was increasing with plant age and significantly higher at 110 day after emergence (Fig. 9b).

\section{Transcriptome analysis}

The transcriptome sequencing was performed using BGISEQ-500 platform, and total 60,222 genes were detected. The FPKM method was used to identify the genes with different expression levels. The results showed that a total of 17,645 genes were significantly changed. Among these genes, 11,696 genes were upregulated and 5949 genes downregulated after 110 days transforming Lxx18460. The differentially expressed genes were subjected into GO enrichment analysis to characterize the major biological functions. The most common terms were "metabolic process", "cell"/"cell part", and "catalytic activity" in each of the three main categories (biological process, cellular component, and molecular function), respectively. It was noticed that there were downregulated genes only in the terms "signal transduction", "positive regulation of biological process", "membrane enclosed lumen", "molecular transducer activity", "electron carrier activity", and "structural molecule activity". There were upregulated genes only in the terms "cell Killing", "transcription factor activity", and "protein binding" (Fig. 10). KEGG pathway analysis showed that these differentially expressed genes were involved in $\mathrm{ABC}$ transporters, RNA polymerase, fatty acid degradation, nitrogen metabolism, secondary metabolite synthesis and so on (see Additional file 3). Quantitative real-time PCR was performed on a subset of 8 randomly selected differentially expressed genes to validate the expression data from the BGISEQ RNA-seq analysis. These genes were involved in plant biometabolism, photosynthesis or plant defense reactions, and also included upregulated and downregulated unigenes (see Additional file 4). The expression patterns for all the 8 genes were in agreement with the RNA-seq data. The transcriptomics data have been deposited in NCBI with the accession No. PRJNA498357.

\section{Discussion}

In this study, the full-length $L x x 18460$ gene, the anti o factor of $L x x$ was cloned and characterized. It was found that the amino acid sequence has low homology with those from other strains, so it is speculated that most o factor homology is not high between different bacterial strains. Since the anti o factor has huge differences in structure and sequence, the bacteria could respond to the stimulus elements, which could better regulate certain gene transcriptions and expressions. Studies have shown that the concentration of $L x x$ in sugarcane is different in various tissues, and the $L x x$ titers decreasing from the basal part to the tail of stalk in sugarcane [23]. Therefore, the expression of $L x x 18460$ in infected plant 

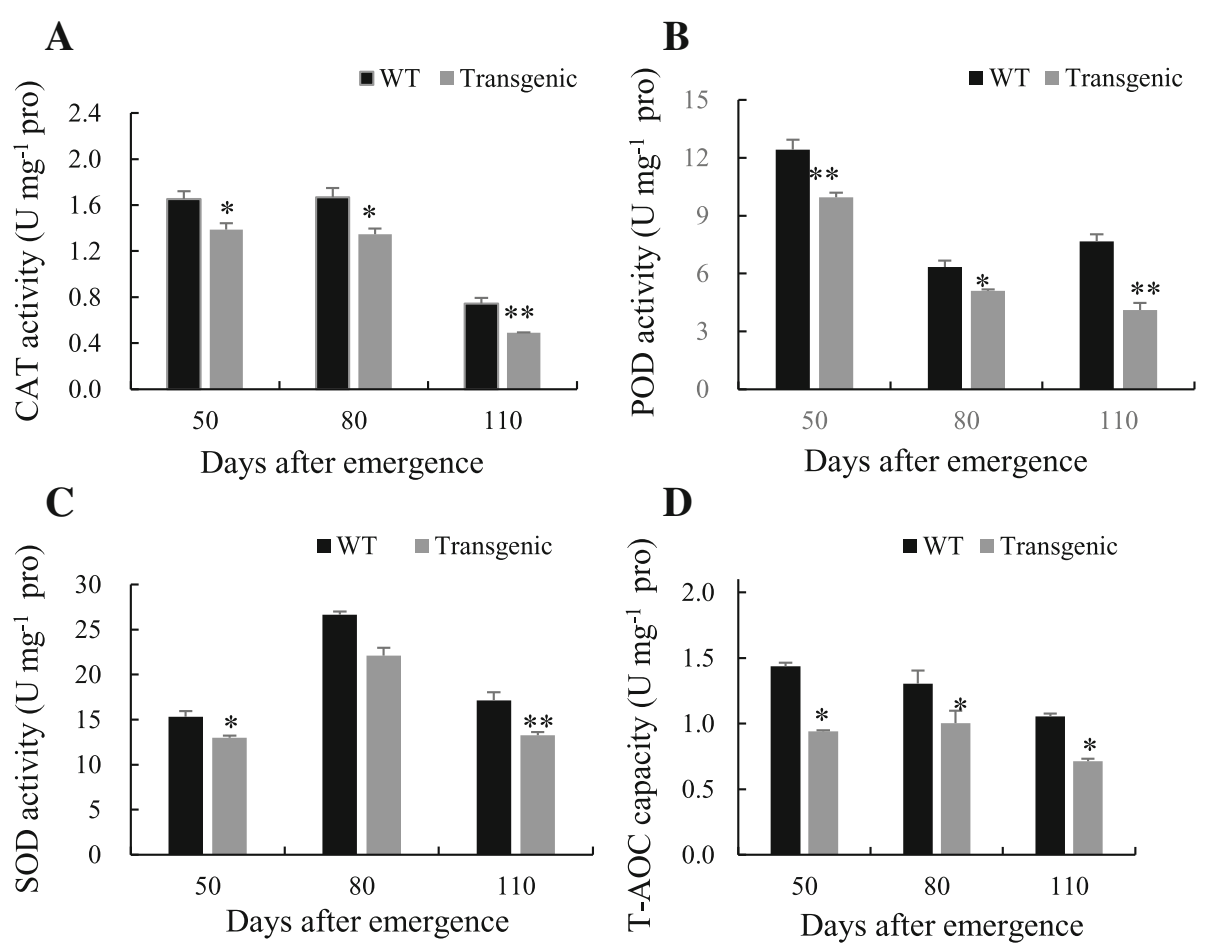

Fig. 6 Activities of SOD, POD, CAT and T-AOC in transgenic and WT tobacco leaves. Tobacco leaf samples were taken at 50, 80 and110 days after emergence. Data are means \pm SD calculated from six replicates. Symbols* and ** indicate significant difference between lines at 0.05 and 0.01 levels, respectively. a, CAT activity; b, POD activity; c, SOD activity; $\mathbf{d}$, T-AOC capacity

is related to the level of $L x x$ in different organs of sugarcane. We used the purified protein of Lxx18460 to obtain monoclonal antibody, which can be used for qualitative and quantitative detection of Lxx18460 protein. In addition, it can be used to further explore the colonization of the bacterium- $L x x$ at transcription and translation levels using $L x x 18460$ gene.

$\mathrm{Li}$ et al. [24] constructed the eukaryotic expression vector of TA3-13, which is a gene coding for the fragment of a cold shock protein WCP1 of wheat (Triticum aestivum L.), and transformed it into tobacco; the transgenic tobacco showed significant resistance against Tobacco mosaic virus and rot pathogen Pectobactrium carotovorum subsp. carotovorum. Tang et al. [25] transformed Sugarcane mosaic virus (ScMV) coat protein $(C P)$ gene into sugarcane variety Badila, and the transgenic sugarcane of $S c M V-C P$ gene significantly enhances the $S c M V$ resistance of sugarcane and improve the cane yield and quality greatly. In this study, we analyzed the function of $L x x$ membrane protein gene $L x x 18460$ (anti-sigma K) by transforming it into tobacco, and then investigated the phenotypic, physiological, biochemical and molecular changes in the transgenic tobacco plants. We found that the net photosynthetic rate was lower in the transgenic tobacco than that in WT plants. The reason may be that $L x x 18460$ gene inhibited the expression of photosynthetic enzyme genes, and this speculation was confirmed by quantifying the relative expression of photosynthesis related genes using RT-PCR. We observed that the expression of Rubisco and PEPC genes were inhibited in the transgenic tobacco. Yu et al. [26] reported that the net photosynthetic rate in tomato decreased after infected with tomato yellow leaf curl virus. Sun [27] found that 51 down-regulated genes coded the proteins involved in photosynthesis in rice after blast infection, and the pathogen suppressed the photosynthesis genes' expression and decreased the photosynthesis greatly. Plant could form an antioxidant protection mechanism to remove excess free radicals, and the defense enzymes of SOD, POD and CAT play a very important role in scavenging reactive oxygen species (ROS) [28-30]. Excessive expression of SOD enzyme in transgenic tobacco can increase the tolerance under stress [31]. POD activity in alfalfa increased after infection by brownblotch strains [32], while CAT activity in tobacco increased after infected by pseudomonas solanacearum [33]. In this study, the SOD, POD and CAT and T-AOC activities in the $L x \times 18460$ transgenic tobacco declined as compared to the WT plants, which suggested that the defense capability had been decreased by transformation of $L \times 18460$ gene. The transcriptome analysis results also showed that the expression of catalase was decreased. The transgenic plants were more susceptible to membrane damage compared to the WT plants. The 


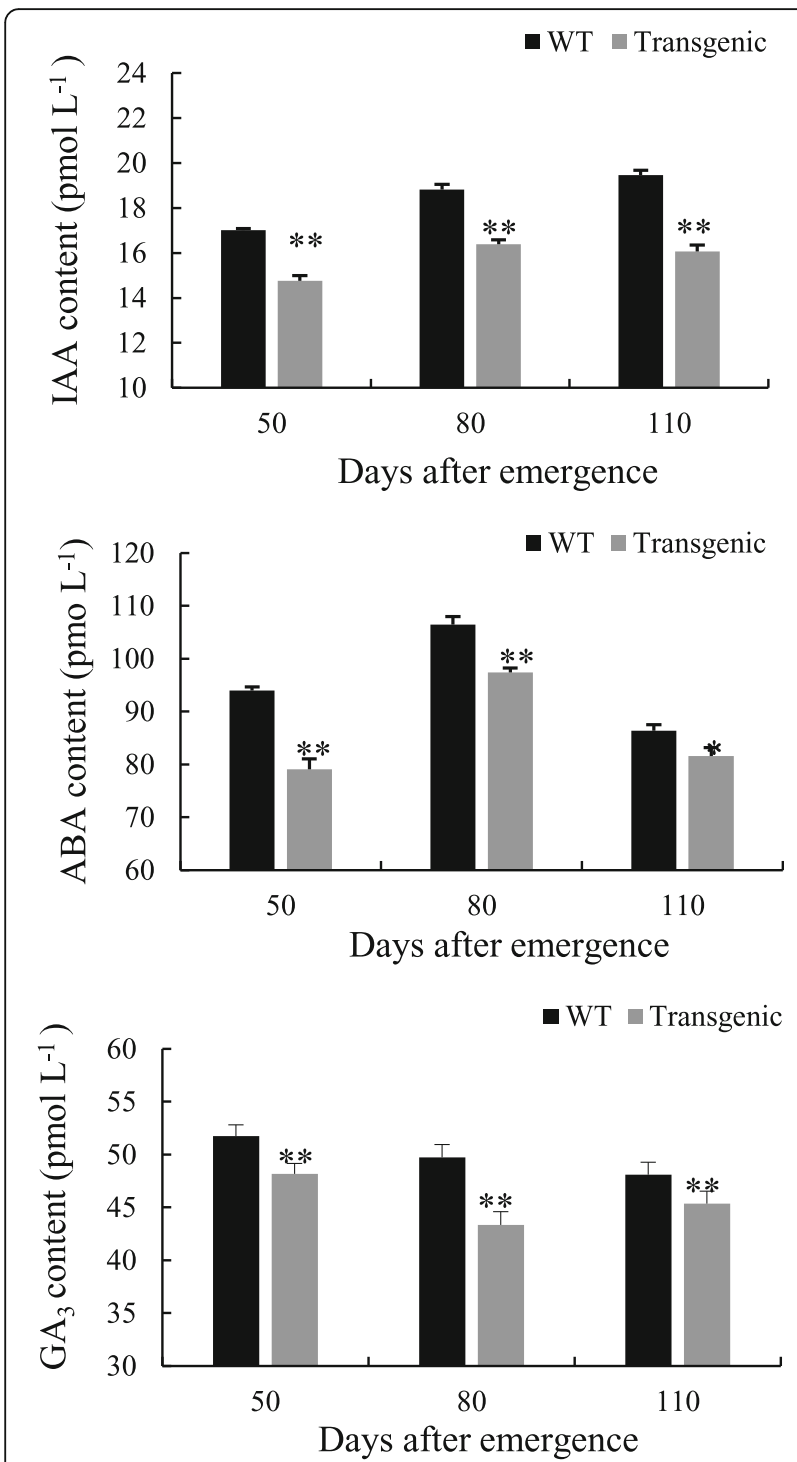

Fig. $7 \mid A A, G A_{3}$ and $A B A$ contents in leaves of transgenic and $W T$ tobacco plants. The measurements were repeated for five times at each sampling date. Data are means \pm SD calculated from three replicates. Symbols * and ** indicate significant difference between lines at 0.05 and 0.01 levels, respectively. Six separate experiments were performed, which produced similar results. a IAA content; $\mathbf{b}$ ABA content and; $c \mathrm{GA}_{3}$ content

pathogen $L x x$ showed extremely strong infection effect though it had been diluted for hundreds of times [34]. It might be possible that at the beginning of the infection, the expression of $L x \times 18460$ gene in pathogenic bacteria inhibits the gene transcription of the defense enzymes and damage the defense regulation of host plants, which would help the pathogen to infect the host and to multiply inside the plant cell. Growth of plant is not only affected by the change of various enzyme activities, but also regulated by various endogenous hormones [35]. According to the results of this study, the syntheses of
$\mathrm{GA}_{3}$, IAA and $\mathrm{ABA}$ were inhibited in the $L x \times 18460$ transgenic plants, which suggested that the expression of Lxx18460 gene suppresses the biosynthesis and signaling pathways of the endogenous hormones. The physiological and phenotypic changes in the transgenic tobacco proved that $L x x 18460$ plays a role in inhibiting the signal transduction and hormone synthesis gene expression.

It has been reported that the photosynthesis and cane yield were decreased, and defense enzyme activities and endogenous hormone levels were adversely affected by the infection of $L x x$ [36-39]. Interestingly, the symptoms of $L x \times 18460$ gene expression in tobacco are similar to those caused by $L x x$ in sugarcane. After transforming the gene $L x x 18460$ into tobacco, the net photosynthetic rate was decreased and the endogenous hormone synthesis inhibited, and the growth of transgenic plants hindered. As the result the plant height was lower and the leaf area smaller, subsequently, the plants become dwarf and smaller, and the biomass decreased. Furthermore, this study demonstrated that the expression level of Lxx18460 gene and Lxx18460 protein was stably increased with time course during plant growth. The results strongly supported the view that the $\operatorname{Lxx} 18460$ gene had been transformed into tobacco, and its expression had slowed down the growth of the transgenic tobacco plants. The higher expression showed the Lxx18460 gene, the more obvious was the effect on transgenic tobacco.

\section{Conclusion}

The membrane protein gene $L x x 18460$ of anti-sigma K (oK) factor in Leifsonia xyli subsp. xyli in sugarcane was cloned, and its structure and expression in sugarcane infected by RSD were analyzed. The function of $L x x 18460$ gene was analyzed by transforming it into tobacco. The results showed that the expression of $L x x 18460$ gene could inhibit the growth of the transgenic tobacco. Lxx18460 gene plays an important role in regulating signal transduction, gene transcription and plant growth, and in the course of infection in sugarcane. It is important to further investigate the function of $L x x 18460$ gene and its role in $L x x$ pathogen. This is the first report of analyzing the function of the membrane protein gene Lxx18460 of anti-sigma $\mathrm{K}(\sigma \mathrm{K})$ factor in Leifsonia xyli subsp. $x y l i$. It is necessary to further investigate the interaction between sugarcane and $L x x$ using $L x x 18460$ gene to illustrate the molecular mechanism of $L x x$ infection in sugarcane.

\section{Materials and methods Materials}

The $L x x$-infected sugarcane (Saccharum spp.) variety GT11 grown in the Sugarcane Institute, Guangxi University (Nanning, China, $108^{\circ} 19^{\prime} \mathrm{E} 22^{\circ} 49^{\prime} \mathrm{N}$ ) was used for 

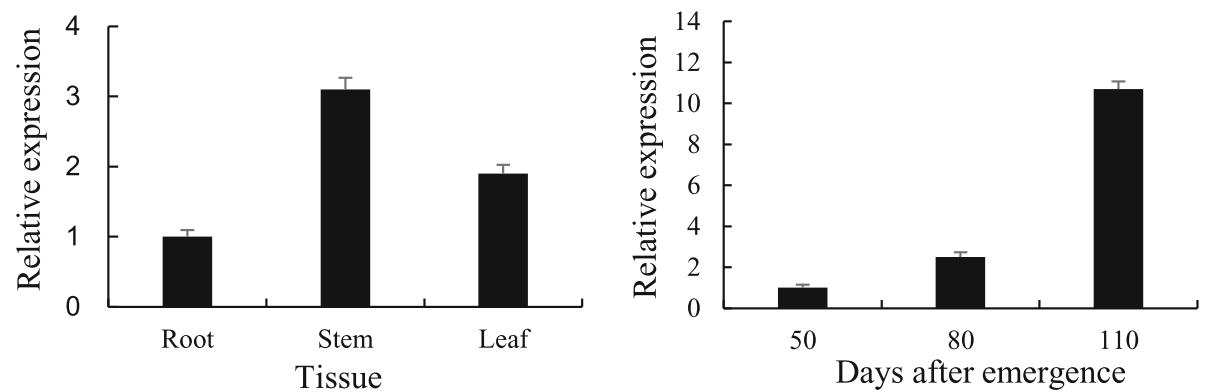

Fig. 8 Relative expression of $L x \times 18460$ gene in transgenic tobacco plants. a, Relative expression of $L x \times 18460$ gene in root, stem and leaf of transgenic tobacco plants at 110 day after emergence. $\mathbf{b}$, Relative expression of $L \times 18460$ gene in transgenic tobacco leaves in different days after emergence

cloning Lxx18460. The wild type tobacco (Nicotiana tabacum L. variety 346) was used for transgenic analysis.

\section{Cloning and sequencing of $L x \times 18460$ gene}

Total RNA from the $L x x$-infected sugarcane stalk was extracted using Trizol Reagent (Cowin Biosciences, Beijing, China) [40], and the cDNA template for RACE-PCR amplification was prepared according to the User Manual (TaKaRa, Dalian, China). Based on the sequence of $L \times x 18460$ from the GenBank (NC-006087), we design the specific primers as R1: 5'-ATGACCGAC GACGAGCGGGG-3' and R2: 5' TCAGGAGGC GATGCCTACGA-3' using Primer Premier 5.0 software. The putative full length $L x x 18460$ gene was obtained using RT-PCR technique. The reaction procedure was as follows: $10 \mathrm{~min}$ at $95^{\circ} \mathrm{C}$ for degeneration, 40 cycles for

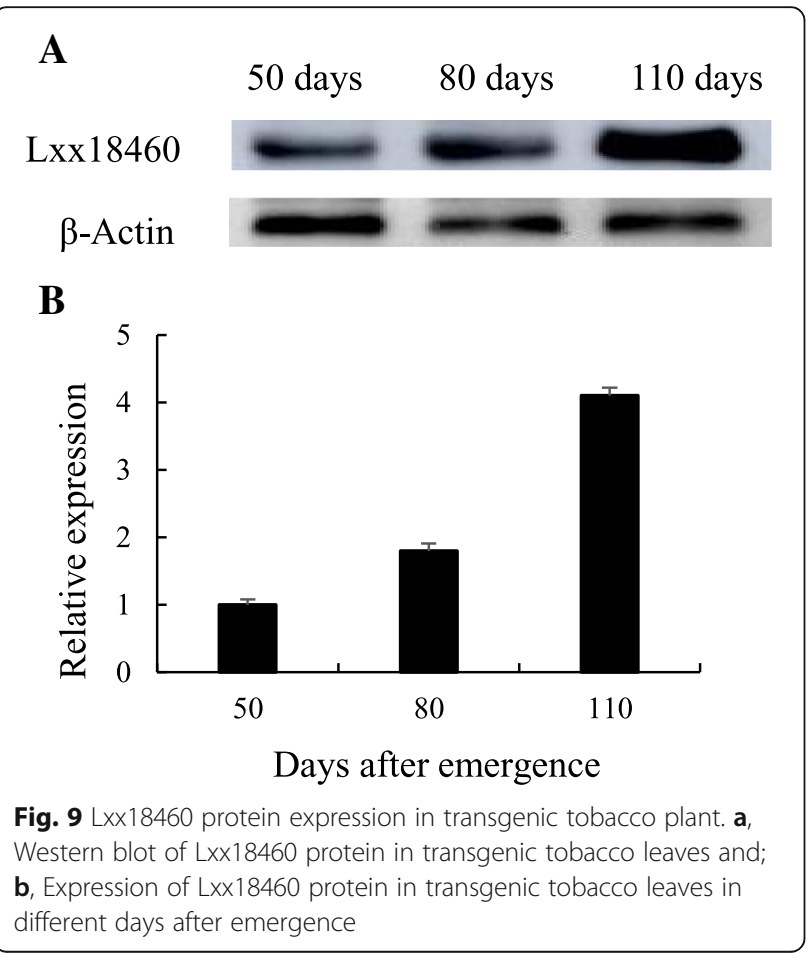

$40 \mathrm{~s}$ at $94{ }^{\circ} \mathrm{C}$, for $40 \mathrm{~s}$ at $62^{\circ} \mathrm{C}$, for $90 \mathrm{~s}$ at $72{ }^{\circ} \mathrm{C}$, and a final extension for $10 \mathrm{~min}$ at $72^{\circ} \mathrm{C}$. The amplified target bands were recovered and purified with a Gel Extraction Kit (TaKaRa, Dalian, China), and then attached to pMD18-T vector (TaKaRa, Dalian, China), transformed into DH5a competent cells (Transgene, Beijing, China); and the positive clones were identified by sequencing.

BLAST (https://blast.ncbi.nlm.nih.gov/Blast.cgi) was used to analyze the sequence in the NCBI database. The physical properties of the $L x x 18460$ protein were predicted using Expasy (http://web.expasy.org/protparam/). Conservative structure and function of the gene encoded protein domains were analyzed using NCBI CDD (Conserved Domain Databases), SMART (http://smart. embl-heidelberg.de/). Transmembrane structures of the protein were analyzed using TMPRED Server (http://embnet. vital-it.ch/software/TMPRED_form.html) and TMHMM2.0 (http://www.cbs.dtu.dk/services/TMHMM/).

Quantitative real-time PCR (qRT-PCR) analysis of $L x x 18460$ expression in $L x x$-infected sugarcane and transgenic tobacco

Quantitative real-time PCR technique was applied to detect the expression of $L \times x 18460$ in different stalks and leaves during the mature growth stages. Internodes 1-7 represent the first to the seventh internode form the base of sugarcane, and leaves +1 to leaf +5 are the first to the fifth leaf with visible dewlap from sugarcane morphological upper part on the ground. The qRT-PCR was done according to the method outlined by Zhu et al. [41]. We calculated the relative level of gene expression using the $2^{-\Delta \Delta C t}$ formula [42]. For transgenic tobacco, the $L x x 18460$ gene expression was measured at 50 to 110 days after emergence. The GAPDH sugarcane gene (accession number EF189713) and GAPDH tobacco gene (accession number M14419) were used as the internal controls to quantify the relative transcript levels in $L x x$-infected sugarcane and transgenic tobacco, respectively $[43,44]$. 


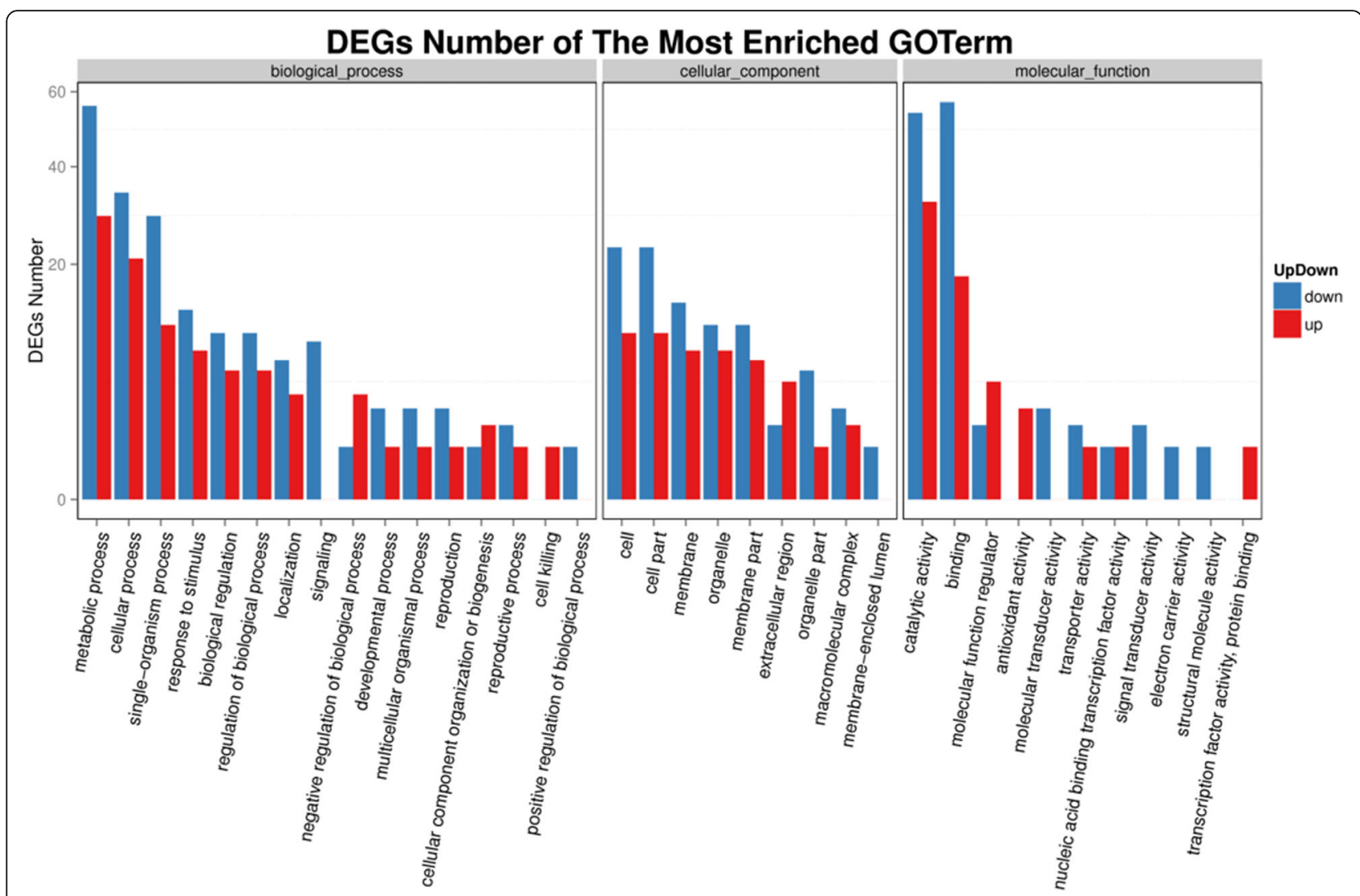

Fig. 10 Differential gene GO functional classification map compared Lxx18460 transgenic with WT tobacco plants

Lxx18460 protein prokaryotic expression, tobacco Lxx18460 transformation and transgenic plant generation The $L x x 18460$ expression vector primers were designed according to the $L x x 18460$ gene ORF. EcoR I endonuclease site, Xho I endonuclease site and protective base pair were added to the $5^{\prime}$ terminal of the primer for gene expression detection. The prokaryotic expression vector pET-30a was transformed into E. coli BL21(DE3)pLysS. After the IPTG induction process, the protein was isolated, purified and analyzed by SDS-PAGE with Image Lab 5.0 software. The protein was identified and confirmed by mass spectrometry (MALDI-TOF). The protein induced and over-expressed in E. coli was used as antigen to produce monoclonal antibody. ELISA test was applied to analyze the titer. The specificity was analyzed using Western blot in bacteria and in the healthy and $L x x$-infected sugarcane plant samples.

The full length open reading frame (ORF) of Lxx18460 was cloned using PCR technique, and then inserted into a pBI121 vector (conserved by our lab). This vector was under control of cauliflower mosaic virus 35S (CaMV35S) promoter and nopaline synthase (NOS) terminator [45]. The recombinant plasmid pBI121-Lxx18460 construction was introduced into the Agrobacterium tumefaciens strain EHA 105, and then transformed into the WT tobacco callus as described by Horsch et al. [46].

The tobacco seeds were sterilized with $70 \%$ ethanol for $30 \mathrm{~s}$ and then rinsed with sterile $\mathrm{ddH}_{2} \mathrm{O}$ two times, followed by disinfection for $8-10 \mathrm{~min}$ in $4 \%$ sodium hypochlorite, rinsing with sterile $\mathrm{ddH}_{2} \mathrm{O}$ five times before they were sown in plate culture medium (M1) based on MS medium [47] supplemented with $25 \mathrm{~g} \mathrm{~L}^{-1}$ sucrose and $0.7 \%$ agar ( $\mathrm{pH} 5.8$ ). The infected explants were co-cultured on M1 medium complemented with $1 \mathrm{mg}$ $\mathrm{L}^{-1}$ 6-benzyladenin (BA) and $0.5 \mathrm{mg} \mathrm{L}^{-1}$ indoleacetic acid (IAA), which is defined as M2 medium, at $25^{\circ} \mathrm{C}$ in dark for 4 days. Then the co-cultured plants were rinsed with $\mathrm{ddH}_{2} \mathrm{O}$ containing $300 \mathrm{mg} \mathrm{L}^{-1}$ cephalosporin. Positive transgenic plants were selected on M2 medium containing $100 \mathrm{mg} \mathrm{L}^{-1}$ of kanamycin. The kanamycin-resistant shoots were transferred to M3 selection medium (M1 medium plus $0.5 \mathrm{mg} \mathrm{L}^{-1}$ IAA, $75 \mathrm{mg} \mathrm{L}^{-1}$ kanamycin) for rooting. A few days later, the non-transgenic and transgenic status of the $\mathrm{T} 1$ plantlets was confirmed by PCR and Western blot analysis.

The T1 plants were just used for phenotypic observation. Seeds of wild type and the transgenic T1 plants were harvested and used for further experiments. The 
expression of $L x \times 18460$ in the independent T2 generation was also determined by PCR and Western blot. For physiological and biochemical analysis, the seedlings were grown in the glasshouse condition. During the T2 generation growth period, $L x x 18460$ expression was observed and analyzed in the transgenic and WT plants using the same method as described above.

\section{PCR identification of transgenic tobacco}

The genomic DNA was extracted from the leaves of transgenic and WT tobacco plants using a modified SDS extraction method [48], and tested for the presence of target gene of $L \times x 18460$ and marker gene of NPTII. The PCR reaction and PCR procedure was described in Additional file 5 .

Western blot analysis of Lxx18460 in transgenic tobacco Total protein was extracted from the leaves of transgenic and WT tobacco plants using a modified phenol extraction method [49], and quantified by spectrophotometer. Western blot was processed as described by Zhu et al. [41].

\section{Plant height, leaf area and net photosynthetic rate measurements}

Plant height was measured from the transgenic and WT tobacco stalk at 50, 80, and 110 days after emergence, respectively. Leaf area was measured using CI-203 Handheld Leaf Area Meter (CID Bio-Science, Inc., Camas, USA). Net photosynthetic rate was measured using Li-6400 photosynthesis system (LI-COR, Lincoln, USA).

\section{Activities of superoxide dismutase (SOD), peroxidase} (POD), catalase (CAT) and total antioxidant capacity (T$A O C)$ assay

Activities of SOD, POD, CAT and T-AOC were measured from leaves of the transgenic and WT tobacco at 50, 80 and 110 days after emergence, respectively. The enzymes were extracted from $0.5 \mathrm{~g}$ leaf and grounded in $2 \mathrm{~mL}$ extraction buffer containing $0.1 \mathrm{M}$ phosphate buffer ( $\mathrm{pH}$ 7.4) and $1 \%$ polyvinylpyrolidone using a mortar and pestle kept in ice bath. The homogenate was centrifuged at $10,000 \times \mathrm{g}$ for $10 \mathrm{~min}$ at $4{ }^{\circ} \mathrm{C}$ and the supernatant was used for enzyme assay. The SOD activity was measured using the nitro-blue tetrazolium method [50]. The activity of POD was measured using the guaiacol method [51]. The activities of CAT and T-AOC were measured using CAT and T-AOC Assay Kit (Jiancheng, Nanjing, China) according to the User Manual.

\section{Contents of IAA, $A B A$ and $G_{3}$ assay}

The fresh leaves of transgenic and WT tobacco were sampled at 50, 80 and 110 days after emergence, respectively. The plant hormone was extracted from $1 \mathrm{~g}$ leaf with $2 \mathrm{~mL}$ extract buffer ( $80 \%$ methanol containing $1 \mathrm{mM}$ butylated hydroxytoluene) and grounded into homogenate in ice bath. Then solution containing $0.1 \%$ Tween- 20 and $0.1 \%$ gelatin phosphate buffer, $\mathrm{pH}$ 7.5) was used to dissolve the hormone extract. The extracts were analyzed using ELISA method with five repeats [52].

\section{BGISEQ-500 sequencing and transcriptome analysis}

Total RNA of each sample was extracted using the Trizol Reagent (Cowin Biosciences, Beijing, China) according to the manufacturer's protocol from three biological replicates of each treatment (WT and Transgenic) resulting in 6 samples. The total RNA concentration of each sample was estimated using a Agilent 2100 Bioanalyzer (Agilent Technologies Inc.). The integrity of the RNA samples was assessed with $1.2 \%$ agarose gel electrophoresis. The six samples were sequenced using BGISEQ-500 Sequencing performed by Beijing Genomics Institute (BGI)-ShenZhen, China according to the manufacturer's instructions. Detailed BGISEQ-500 sequencing experimental process and transcriptome data analysis method refer to Additional file 6.

\section{Data analysis}

All the data were analyzed using Microsoft Excel 2003 (Microsoft) and IBM SPSS 21.0. All data points represent means from 15 plants of transgenic or WT tobacco. There were three technical replicates for each experiment, and statistical differences were compared based on the Duncan's test with $P$ values set at 0.05 and 0.01 levels, respectively, and means were compared by standard error (SE).

\section{Additional files}

Additional file 1: Nucleotide, predicted amino acid sequences (A) and conserved domain (B) of Lxx18460. (DOCX $102 \mathrm{~kb}$ )

Additional file 2: Identification of transgenic tobacco plants detected with PCR. (DOCX $198 \mathrm{~kb})$

Additional file 3: KEGG pathway analysis of DEGs in $L x x 18460$ transgenic tobacco. (DOCX $541 \mathrm{~kb}$ )

Additional file 4: Quantitative real-time PCR analysis of selected DEGs in LXX18460 transgenic tobacco. (DOCX $38 \mathrm{~kb}$ )

Additional file 5: PCR identification of transgenic tobacco. (DOCX $16 \mathrm{~kb}$ )

Additional file 6: BGISEQ-500 sequencing and transcriptome analysis, the primers of DEGs validated by qRTPCR analysis. (DOCX $21 \mathrm{~kb}$ )

\footnotetext{
Abbreviations

ABA: Abscisic acid; BA: 6-benzyladenin; bp: Base pair; CAT: Catalase; CDNA: Complementary DNA; FPKM: Fragments per kilobase of transcript per million mapped reads; FW: Fresh weight; $\mathrm{GA}_{3}$ : Gibberellic acid; GAPDH: Glyceraldehyde-3-phosphate dehydrogenase; IAA: Indoleacetic acid; Lxx: Leifsonia xyli subsp. Xyli; NCBI: National Center for Biotechnology Information; Nt: Nicitiaba tabacum; OK: Anti-sigma K; ORF: Open reading frame; PEPC: Phosphoenolpyruvate carboxylase; pl: Isoelectric point; POD: Peroxidase; RACE: Rapid amplification of cDNA ends; ROS: Reactive oxygen species; RSD: Ratoon stunt disease; RT-PCR: Reverse transcription-
} 
polymerase chain reaction; SDS: Sodium dodecyl sulfate; SOD: Superoxide dismutase; TT: Transgenic tobacco; WT: Wild type

\section{Acknowledgements}

We acknowledge Mr. Dajie Zhou from Beijing Genomics Institute (Shenzhen) for the assistance of transcriptome sequencing.

\section{Funding}

The present study was supported by National Natural Science Foundation of China (31360293), International Scientific Cooperation Program of China (2013DFA31600), Guangxi Special Fund for Scientific Base and Talent (GKAD17195100), Guangxi Special Funds for Bagui Scholars and Distinguished Experts (2013-3), Guangxi Natural Science Fund (2011GXNSFF018002, 2012GXNSFDA053011), and Guangxi Sugarcane Innovation Team of National Agricultural Industry Technology System (gjnytxgxcxtd-03-01). The funding bodies played no role in the design, execution, interpretation of the data, or writing of the manuscript.

\section{Availability of data and materials}

Clean data (FASTQ files) for all samples can be accessed in the NCBI Sequence (https://www.ncbi.nlm.nih.gov/sra) under the accession number of PRJNA498357.

\section{Authors' contributions}

L.T.Y. and Y.R.L. designed the study. K.Z., M.S., D.Z., and Y.X.X. conducted the experiments. K.Z. analyzed the data. K.Z., L.T.Y. and Y.R.L. wrote the manuscript. L.T.Y. and Y.R.L. revised and finalized the manuscript. All authors read and approved the final manuscript.

\section{Ethics approval and consent to participate}

No specific permits were required for the described field studies. The location is not privately-owned or protected in any way, and the field studies did not involve endangered or protected species.

\section{Consent for publication}

Not applicable.

\section{Competing interests}

The authors declare that they have no competing interests.

\section{Publisher's Note}

Springer Nature remains neutral with regard to jurisdictional claims in published maps and institutional affiliations.

\section{Author details}

'College of Agriculture, State Key Laboratory of Conservation and Utilization of Subtropical Agro-bio resources, Guangxi University, Nanning 530005, China. ${ }^{2}$ Ministry of Agriculture Key Laboratory of Sugarcane Biotechnology and Genetic Improvement (Guangxi), Guangxi Key Laboratory of Sugarcane Genetic Improvement, Sugarcane Research Center, Chinese Academy of Agricultural Sciences-Guangxi Academy of Agricultural Sciences, Nanning 530007, China.

Received: 6 September 2018 Accepted: 19 December 2018

Published online: 07 January 2019

\section{References}

1. Li YR. Modern sugarcane sciences. Beijing: China Agriculture Press; 2010

2. Li YR, Yang LT. Sugarcane agriculture and sugar industry in China. Sugar Tech. 2015. https://doi.org/10.1007/s12355-014-0342-1.

3. Davis MJ, Gillaspie AG Jr, Harris RW, Lawson RH. Ratoon stunting disease of sugarcane: isolation of the causal bacterium. Science. 1980;210:1365-7.

4. Haapalainen M, Mattinen J, Metzler MC. The growth of a plant-parasitic bacterium, Clavibacter xyli subsp cynodontis, is enhanced by xylem fluid components. Physiol Mol Plant Pathol. 2000. https://doi.org/10.1006/pmpp. 2000.0260.

5. Dean JL. Single-stool plots for estimating relative yield losses caused by ratoon stunting disease of sugarcane. Plant Dis. 1983. https://doi.org/10. 1094/PD-67-47.
6. Grisham MP. Effect of ratoon stunting disease on yield of sugarcane grown in multiple three-year plantings. Phytopathology. 1991. https://doi.org/10. 1094/Phyto-81-337.

7. Li WF, Shen K, Huang YK, Wang XY, Luo ZM, Ying XM, Yin J, Ma L, Shan HL, Zhang RY. PCR detection of ratoon stunting disease pathogen and natural resistance analysis in sugarcane core germplasms. Crop Prot. 2013. https:// doi.org/10.1016/j.cropro.

8. Young AJ. Possible origin of ratoon stunting disease following interspecific hybridization of Saccharum species. Plant Pathol. 2016. https://doi.org/10. 1111/ppa.12545.

9. Maramorosch K, Plavsic-Banjac B, Bird J, Liu L. Electron microscopy of ratoon stunted sugar cane: microorganisms in xylem. Phytopathology. 1973;77:270-3.

10. Quecinea MC, Silvaa TMG, Carvalhoa SS, Mondina M, Teixeira-Silva NS, LEA C, Monteiro-Vitorello CB. A stable Leifsonia xyli subsp. xyli GFP-tagged strain reveals a new colonization niche in sugarcane tissues. Plant Pathol. 2015. https://doi.org/10.1111/ppa.12397.

11. Fegan $M$, Croft BJ, Teakle DS. Sensitive and specific detection of Clavibocter xyli subsp. xyli, causative agent of ratoon stunting disease of sugarcane, with a polymerase chain reaction-based assay. Plant Pathol. 1998. https:// doi.org/10.1046/j.1365-3059.

12. Monteiro-Vitorello CB, Camargo LE, Van Sluys MA, Kitajima JP, Truffi D, do Amaral AM, Harakava R, de Oliveira JC, Wood D, de Oliveira MC, Miyaki C, Takita MA, da Silva AC, Furlan LR, Carraro DM, Camarotte G, Almeida NF Jr, Carrer H, Coutinho LL, El-Dorry HA, Ferro MI, Gagliardi PR, Giglioti E, Goldman MH, Goldman GH, Kimura ET, Ferro ES, Kuramae EE, Lemos EG, Lemos MV, Mauro SM, Machado MA, Marino CL, Menck CF, Nunes LR, Oliveira RC, Pereira GG, Siqueira W, de Souza AA, Tsai SM, Zanca AS, Simpson AJ, Brumbley SM, Setúbal JC. The genome sequence of the grampositive sugarcane pathogen Leifsonia xyli subsp. xyli. Mol Plant Microbe Interact. 2004. https://doi.org/10.1094/MPMI.2004.17.8.827.

13. Kao J, Damann KE. Microcolonies of the bacterium associated with ratoon stunting disease found in sugarcane xylem matrix. Phytopathology. 1978;68:545-51.

14. Kao J, Damann KE. In situ localisation and morphology of the bacterium associated with ratoon stunting disease of sugarcane. Canadian J Bot. 1980; 58:310-5.

15. Chan ZL, Wang $Q$, Xu XB, Meng XH, Qin GZ, Li BQ. Functions of defenserelated proteins and dehydrogenase in resistance response induced by salicylic acid in sweet cherry fruits at different maturity stages. Proteomics. 2008. https://doi.org/10.1002/pmic

16. Urbauer JL, Simeonov MF, Urbauer RJ, Adelman K, Gilmore JM, Brody EN. Solution structure and stability of the anti-sigma factor AsiA: implications for novel functions. PNAS. 2002. https://doi.org/10.1073/pnas.032464699.

17. Park ST, Kang CM, Husson RN. Regulation of the SigH stress response regulon by an essential protein kinase in Mycobacterium tuberculosis. PNAS 2008. https://doi.org/10.1073/pnas.0801143105.

18. Lourenço RF, Kohler C, Gomes SL. A two-component system, an anti-sigma factor and two paralogous ECF sigma factors are involved in the control of general stress response in Caulobacter crescentus. Mol Microbiol. 2011. https://doi.org/10.1111/j.1365-2958.

19. Campbell EA, Tupy JL, Gruber TM, Wang S, Sharp MM, Gross CA, Darst SA. Crystal structure of Escherichia coli oE with the cytoplasmic domain of its anti- $\sigma$ RseA. Mol Cell. 2003. https://doi.org/10.1016/S1097-2765(03)00148-5.

20. Said-Salim B, Mostowy S, Kristof AS, Behr MA. Mutations in Mycobacterium tuberculosis Rv0444C, the gene encoding anti-SigK, explain high level expression of MPB70 and MPB83 in Mycobacterium bovis. Mol Microbiol. 2006. https://doi.org/10.1111/j.1365-2958.2006.05455.x.

21. Donohue TJ. Targeted ơ factor turnover inserts negative control into a positive feedback loop. Mol Microbiol. 2009;73:747-50.

22. Bai H, Yan H, Hou Z, Yu Q, Luo XX. The research progress on the units of bacteria RNA polymerase. Prog Physiol Sci. 2011;42:47-51.

23. Grisham MP, Pan YB, Richard JEP. Early detection of Leifsonia xyli subsp. xyli in sugarcane leaves by real-time polymerase chain reaction. Plant Dis. 2007; doi: https://doi.org/10.1094/PDIS-91-4-0430.

24. Li N, Du XZ, Pan XM, Wang JS, Song CF. Study on the transgenic tobacco expressing truncated wheat cold shock protein gene TA3-13 and analysis of disease resistance. Hereditas. 2011:33:520-6.

25. Tang XD. The evaluation of SCMV-CP gene transgenic sugarcane. Fujian Agriculture and Forestry University. Master's thesis. 2009;

26. Yu L, Guo SR, Zhu WM, Yan J, Hei YX. Effects of tomato yellow leaf curl virus on photosynthetic characteristics and chloroplast ultra-structure of the tomato leaves. Acta Botan Boreali-Occiden Sin. 2011;31:1355-9. 
27. Sun LX. SAGE analysis of transcriptome response in rice leaves during hostfungal pathogen interactions. Dissertation, Institute of Plant and Ecology, SIBS, CAS. 2005;

28. Blokhina O, Virolainen E, Fagerstedt KV. Antioxidants, oxidative damage and oxygen deprivation stress: a review. Ann Bot. 2003. https://doi.org/10.1093/ aob/mcf118.

29. Jaleel AC, Riadh K, Gopi R, Manicannan P, Ines J, Al-Juburi HJ, Zhao CX, Shao HB, Panneerselvam R. Antioxidant defense responses: physiological plasticity in higher plants under abiotic constraints. Acta Physiol Plant. 2009;31:427-36.

30. Huang XS, Liu JH, Chen XJ. Overexpression of PtrABF gene, a bZIP transcription factor isolated from Poncirus trifoliata, enhances dehydration and drought tolerance in tobacco via scavenging ROS and modulating expression of stress-responsive genes. BMC Plant Biol. 2010. https://doi.org/ 10.1186/1471-2229-10-230.

31. Gupta AS, Heinen JL, Holaday AS, Burke JJ, Allen RD. Increased resistance to oxidative stress in transgenic plants that overexpress chloroplastic $\mathrm{Cu} / \mathrm{Zn}$ superoxide dismutase. PNAS.1993; doi:https://doi.org/10.1073/pnas.90.4.1629.

32. Yuan QH, Gui Z, Zhang WS. Comparison of the activities of SOD, POD and PPO within alfalfa cultivars resistant and susceptible to alfalfa common leaf. Acta Prataculturae Sinica. 2002;11:100-4.

33. Ke $Y Q$, Pan TG, Fang SM. Effect of Pseudomonas solanacearum infection on H2O2 metabolism and chlorophyll fluorescence parameters and their relations to disease resistance. Chin J Eco-Agric. 2002;10:36-9.

34. Li PP, Zhang X, Pan XM, Wang JS, Song CF. His-tag fusion expression, purification and TMV resistance induction of truncated wheat cold shock protein gene fragment TA3-13. J Nanjing Agric Univ. 2010;33:54-8.

35. Fan JJ, Li XM, Ruan YH. Changes in endogenous hormone contents during grain filling in hybrid rice and its parents. Plant Physiol Commun. 2004;40: 146-8.

36. Chen MH, Huang X, Xie XN, Yang LT, Li YR, Chen BS. Effects of ratoon stunting disease on growth and endogenous hormone in sugarcane. J Huazhong Agric Univ. 2013;32:57-61.

37. Johnson SS, Tyagi AP. Effect of ratoon stunting disease (RSD) on sugarcane yield Fiji. South Pacific J Nat Appl Sci. 2010;28:69-73.

38. Zhang XQ, Liang YJ, Tang YX, Shao M. Morphological characteristic of Leifsonia xyli subsp. Xyli and its effects on photosynthesis of sugarcane. J Huazhong Agric Univ. 2015;34:42-7.

39. Zhang XQ, Liang YJ, Zhu K, Wu CX, Yang LT, Li YR. Influence of Inoculation of Leifsonia xyli subsp. Xyli on Photosynthetic Parameters and Activities of Defense Enzymes in Sugarcane. Sugar Tech. 2016. https://doi.org/10.1007/ s12355-016-0479-1.

40. Hogenhout SA, Redinbaugh MG, Ammar ED. Plant and animal rhabdovirus host range: a bug's view. Trends Microbiol. 2003. https://doi.org/10.1016/ S0966-842X(03)00120-3.

41. Zhu K, Yuan D, Zhang XQ, Yang LT, Li YR. The physiological characteristics and associated gene expression of sugar cane inoculated with Leifsonia xyli subsp. xyli. J Phytopathol. 2018. https://doi.org/10.1111/jph.12659.

42. Livak K, Schmittgen T. Analysis of relative gene expression data using realtime quantitative PCR and the $2^{-\mathrm{DDCT}}$ method. Methods. 2001. https://doi. org/10.1006/meth

43. Li J, Phan TT, Li YR, Xing YX, Yang LT. Isolation, transformation and overexpression of sugarcane SoP5CS gene for drought tolerance improvement. Sugar Tech. 2017. https://doi.org/10.1007/s12355-017-0568-9.

44. Phan TT, Sun B, Niu JQ, Tan QL, Yang LT, Li YR. Overexpression of sugarcane gene SoSnRK2.1 confers drought tolerance in transgenic tobacco. Plant Cell Rep. 2016. https://doi.org/10.1007/s00299-016-2004-0.

45. Deng $L$, Liu H, Yang WN. Construction of the recombinant expression plasmid pBl121-GFP-62390 and pBl121-GFP-51780 containing green fluorescent protein gene. J Anhui Agric Sci. 2008;36:11260-2.

46. Horsch RB, Fry JE, Hoffmann NL, Eichholtz D, Rogers SC, Fraley RT. A simple and general method for transferring genes into plants. Science. 1985;227: 1229-31.

47. Murashige T, Skoog F. A revised medium for rapid growth and bio assays with tobacco tissue cultures. Physiol Plant. 1962;15:473-97.

48. Shan Z, Wu HL, Li CL, Chen H, Wu Q. Improved SDS method for general plant genomic DNA extraction. Guangdong Agric Sci. 2011;8:113-5.

49. Yang L, Lin H, Takahashi Y, Chen F, Walker MA, Civerolo EL. Proteomic analysis of grapevine stem in response to Xylella fastidiosa inoculation. Physiol Mol Plant Pathol. 2011. https://doi.org/10.1016/j.pmpp.2010.11.002.
50. Li HS, Sun Q, Zhao SJ, Zhang WH. Principle and technology of physiological and biochemical test in plants. Beijing: Higher Education Press; 2000. p. 195-261.

51. Yang LT, Li YR, Mo JR. Preliminary study on effects of several physiological and biochemical characteristics of sugarcane leaves after the application of "duo Xiao Hao". J Guangxi Agric Coll. 1990;9:79-83.

52. Wu SR, Chen WF, Zhou X. Enzyme linked immunosorbent assay for endogenous plant hormones. Plant Physiol Commun. 1988:53:57.
Ready to submit your research? Choose BMC and benefit from:

- fast, convenient online submission

- thorough peer review by experienced researchers in your field

- rapid publication on acceptance

- support for research data, including large and complex data types

- gold Open Access which fosters wider collaboration and increased citations

- maximum visibility for your research: over $100 \mathrm{M}$ website views per year

At BMC, research is always in progress.

Learn more biomedcentral.com/submissions 